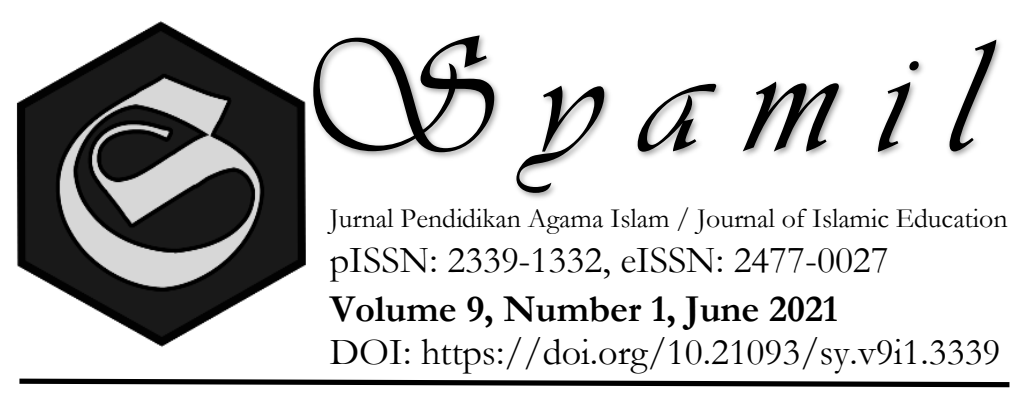

\title{
THE EFFECT OF ONLINE-BASED DISTANCE LEARNING ON STUDENT LEARNING OUTCOMES AT PAI LESSONS AT SMA NEGERI 5 BOGOR
}

\author{
Fauzia Turohmah \\ Universitas Ibn Khaldun Bogor \\ Email: turohmahfauzia11@gmail.com \\ Santi Lisnawati \\ Universitas Ibn Khaldun Bogor \\ Email: santilisnawati@fai.uika-bogor.ac.id
}

\begin{abstract}
Online-based distance learning is an alternative to learning in the current situation. Distance Education is an education whose students are separated from educators, and their learning uses a variety of learning resources through communication technology, internet information, and other media. This study aims to find out how much influence online-based distance learning has on students' learning outcomes in PAI. The research method used is exposed facto research. This type of pining is with primary data and secondary data. The results showed that; Online-based Distance Learning positively and signification of student learning outcomes by $13.3 \%$. Online-based Distance Learning can improve the quality of education to continue to be carried out properly, especially in student learning outcomes even in the condition of the covid-19 pandemic.
\end{abstract}

Keyword: student learning outcomes, PAI, online-based distance learning

\section{A. Introduction}

Today information and communication technology is growing rapidly. Information and communication technology (ICT) systems provide a wide range, fast, effective, and efficient to the spread of information throughout the world ${ }^{1}$. The existence of information and communication technology (ICT) provides

${ }^{1}$ Rusman, Pembelajaran Berbasis Teknologi Informasi Dan Komunikasi (Jakarta: PT Rajagrafindo Persada, 2011). 
benefits in various aspects of life, with no exception in the field of education. To improve the quality of education, innovation is needed in the learning process, this becomes a necessity of the learning process combined with the use of information and communication technology.

Since the beginning of 2020, the world of education has changed drastically. Learning that should be done face-to-face between students and teachers is now diverted into online-based distance learning at all levels of kindergarten, elementary/mi, junior high/MTs/, high school/ma, and college education. This is intended to prevent the transmission of coronavirus (covid-19). The implementation of online-based learning that can be interpreted as learning in the "online" network is following the Circular Letter of the Minister of Education No. 36962 on Learning "online" and working from home to Prevent the Spread of Corona Virus Disease (covid-19). Online-based distance learning is an alternative to learning in the current situation. The term Distance Learning (PJJ) is listed in Law No. 20 of 2003 on The National Education System Article 1 which states that Distance Education is an education whose students are separated from educators, and whose learning uses various learning resources through communication technology, internet information, and other media. ${ }^{2}$ In the teaching and learning process of Islamic education, the presence of learning media is very important and is a must. ${ }^{3}$

Success in learning is influenced by several factors, namely internal and external factors. Both factors influence each other in the individual process to determine the quality of learning outcomes. Internal factors are factors that come from within the self that includes health, intelligence (intelligence), talents and interests, motivation, how to learn, cognitive abilities (self-concept). While external factors are factors that come from outside the self such as family, school, community, the surrounding environment. ${ }^{4}$ The distance learning system requires schools and teachers to be able to take advantage of the online platform as a medium to support the learning process. ${ }^{5}$

Islamic religious education is an education that provides knowledge and forms the attitudes, personalities, and skills of learners in practicing the teachings of Islam, which is carried out at least through subjects on all lines, levels, and types of education. ${ }^{6}$. Therefore, from the description above researchers are interested

2 Kharisma Danag Yungga, "Pengembangan Media Dan Strategi Pembelajaran Untuk Mengatasi Permasalahan Pembelajaran Jarak Jauh Di Pandemi Covid-19," Guru Kita 4, no. 3 (2020): 52.

3 Agus Setiawan, "Merancang Media Pembelajaran PAI di Sekolah (Analisis Implementasi Media Pembelajaran Berbasis PAI)," Darul Ulum: Jurnal Ilmiah Keagamaan, Pendidikan dan Kemasyarakatan, December 1, 2019, 223-240. 4.0, 2020.

${ }^{4}$ Nyoman Supyatningsih, E-Learning Untuk Pembelajaran Abad 21 Dalam Menghadapi Era Revolusi Industri

${ }^{5}$ Apri Wardana Ritonga et al., "The Use of E-Learning as an Online Based Arabic Learning Media for Students," Journal of Physics: Conference Series 1933, no. 1 (June 2021): 012127, https://doi.org/10.1088/17426596/1933/1/012127.

${ }^{6}$ Haidar Putra Daulay, Pemberdayaan Pendidikan Agama ISlam Di Sekolah (jakarta: Kencana, 2016). 
to write a study entitled "Application of Online-Based Distance Learning to Student Learning Outcomes in PAI Lessons".

\section{B. Literature Review}

Distance education is a teaching and learning process that is conducted separately through the use of various communication media. Along with the advancement and sophistication of technology accompanied by internet services there is a change in distance learning using the principle of electronics. The term between electronic objects and learning is (E-Learning). Kamarga about the understanding of e-learning is teaching materials used at the time of learning activities obtained by accessing it through electronic computer devices. According to Linde e-learning is formal and informal learning using electronic media such as the internet, CD-ROM, Videotape, DVD, TV, handphone, PDA, and so on. According to Kartasasmita one of the characteristics of e-learning is the combination of technology with various practical applied and with easy access to learning resources, to teachers, and the same learners through the internet. This makes e-learning likened to an online course, online learning, enabled learning, virtual learning, or web-based learning. But e-learning with online-based distance learning is different. Teaching materials in e-learning can be learned by students offline through VCD / DVD that has been packaged by teachers. It can also be learned online if the teacher packages the material that the teacher has uploaded to the website. While online-based distance learning is learning that can make it easier for both parties because the teaching materials are delivered "online" in the network. Virtual learning is learning that is done using the internet or internet LAN / WAN.

Online-based distance learning is not the same as conventional learning, as for the learning characteristics as follows: 1. Interactivity; the availability of more communication lines, either directly (synchronous), such as chat or messenger, or indirectly (asynchronous), such as forums, mailings, lists, or guestbooks, 2. Independency (Self-Reliance); flexibility in the aspects of providing time, teachers, and teaching materials. This leads to student central learning, 3. Accessibility (Accessibility); learning resources become more accessible by connecting to the internet, 4. Enrichment; learning activities, percentage of learning materials, and exercises as enrichment make it possible to use information technology devices such as streaming video, simulation, and animation.

The platform that is commonly used by educational institutions is zoom meeting and classroom. zoom meeting is a learning medium that uses video. Zoom Meeting application popularized by Eric Yuan which was inaugurated in 2011 whose headquarters are located in San Jose, California. This platform can be used by anyone and is free with forty minutes deadline, no time limit if our account is paid. In the Zoom Meeting application, it's easy to communicate directly with anyone via video. Therefore, it is suitable for use as a learning 
medium. ${ }^{7}$. Google Classroom was chosen as a learning medium. Besides being easy to access and use, this app can be a communication space and interaction between teachers and students in online classes. In its use, google classroom is very easy to use in learning activities. 8

Learning outcomes can be explained by understanding the two words that make up them, "results" and "learning". The understanding of the results (product) shows one acquisition due to the conduct of an activity or process that results in a functional change in input. In the context of teaching, learning is a conscious activity to make students learn. Therefore, the learning outcome is the acquisition of the student learning process in accordance with the teaching objectives (ends are being attained). The purpose of teaching becomes a potential learning outcome that will be achieved by students through their learning activities 9 .

Religious education in general is an effort to make man able to realize the purpose of his creation. People were created so that they may know the nature of His God, To ESA, purify worship to His God, and to be enslaved by living all the land and avoid all prohibitions. Islamic religious education is achieved through materials that are compacted into five main elements, namely, the Qur'an, Faith, Morality, Fiqh, Guidance of Worship, Date or history that emphasizes the development of religious teachings, science, and culture. ${ }^{10}$

The purpose of Islamic education is explained in the Qur'an in the following verses:

Surah Al Baqarah Verse 21

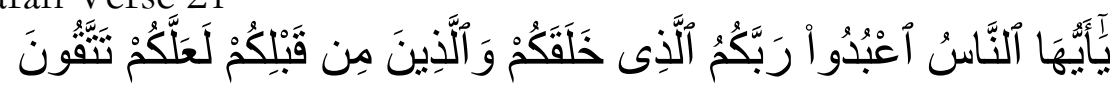

O mankind, worship your Lord who created you and those before you so that you may be god-fearing.

Research conducted by Soniya Istifadiya Wita, 2009 Revealed that data on the use of distance learning methods in PAI materials are very good. This can be seen from the percentage result of $95 \%$. And that figure when consulted with the standard percentage is classified very well. For student learning outcomes in PAI field of study, relatively high, this can be seen from the results of the percentage of student learning outcomes reached a percentage of $87 \%$. Research conducted by Setiawan, the results of this study indicated that 1) students and lecturers are actively involved in the face-to-face learning process and online activities on the e-learning website. These results indicated that a positive potential for education

\footnotetext{
7 Danin Haqien and Aqiilah Rahman, "Pemanfaatan Zoom Meeting Untuk Proses Pembelajaran Pada Masa Covid-19," Sususnan Artikel Pendidikan 5 (2020): 52.

8 Swita Amalia Hapsari and Heri Pamungkas, "Pemanfaatn Google Classroom Sebagai Media Pembelajaran Online Di Universitas Dian Nuswantoro,” WACANA 18 (2019): 229.

${ }^{9}$ Purwanto, Evaluasi Hasil Belajar (Yogyakarta: Pustaka Pelajar, 2009).

${ }^{10}$ Susanto, Belajar Dan Pembelajaran Di Sekolah Dasar (Jakarta: Kencana, 2013).
} 
with blended learning innovation is implemented at public Islamic higher education. 11

\section{Method}

In this study, the authors used quantitative research. Quantitative research is based on the philosophy of positivism that emphasizes objective phenomena that are quantitatively studied. Maximizing the objectives of the design of this study was conducted using numbers, statistical processing, structure, and controlled experiments. ${ }^{12}$. The research method used is exposed facto research. This research is a study conducted after the incident. This research can only be done when an event or event has already occurred, and the event covers free variables and bound variables. ${ }^{13}$. In this study, sampling was conducted using the Purposive sampling technique, which is a sampling technique with certain considerations. in this study, the samples used were students and students of grade X IPS SMA Negeri 5 Bogor which amounted to 107 people. In this study, sampling was conducted using the Purposive sampling technique, which is a sampling technique with certain considerations. For data collection techniques, because this study investigates the phenomenon that has occurred, the author uses several instruments in the study, namely as follows: 1) 1. Through Questionnaires, the questionnaire used was a closed model because the answers had been provided and the measurements with the Likert scale were used to measure the attitudes, opinions, and perceptions of a person or group of people in a social phenomenon. 14. To compose instruments that use the likert scale has a very negative to very positive gradation with 5 (five) alternative answers, Strongly agree, agree, be neutral, disagree, strongly disagree. 2) Documentation, in the form of test results of midterm exam students. Student score test results data is used to uncover variables in student learning outcomes in Islamic Education lessons. The validity test in this study is based on the value of $r$ table and $r$ count, for the value of $r$ table can be known by the value of the degree of freedom (df) $\mathrm{df}=\mathrm{n}-2$ with sig $5 \%$. If $r$ _tabel $<$ r_hitung then valid ${ }^{15}$. In this case, the calculation process is assisted by the IBM SPSS Statistics 22 statistical analysis program. To find out the reliability in this study using the alfa Cronbach formula technique the calculation process is assisted by IBM SPSS Statistics 22 statistical analysis program. To find out the presence of collation between the two variables used Simple Linear Regression analysis with the help of IMB SPSS 22. To test the signification of a relationship, i.e. whether the relationship found applies to all populations, a

11 Agus Setiawan, "Implementation of Islamic Education Study Program Learning Based on Blended Learning in the Industrial Era 4.0 at IAIN Samarinda," Dinamika Ilmu 19, no. 2 (December 15, 2019): 305-321, https://doi.org/10.21093/di.v19i2.1781.

12 Sukmadinata, Model Penelitian Pendidikan (PT Remaja Rosdakarya, 2011).

${ }_{13}$ Muhyani, Metodologi Penelitian, Cara Mudah Melakukan Penelitian (Bogor Jawa Barat: UIKA PRESS, 2019).

14 Sugiyono, Metode Penelitian Kuantitatif, Kualitatif, R\&D (BAndung: Alfabeta, 2013).

15 Selamet Riyanto, Metode Riset Penelitian Kuantitatif (Yogyakarta: Deepublish, 2020). 
signification test is conducted. with significance: $\alpha=0.05$, and degree of freedom $(\mathrm{dk})=\mathrm{n}-2$. The test rules are:

\section{Finding}

The variables of this study consist of one free variable (independent) namely Online-based Distance Learning and one dependent variable that is the student's learning outcomes in PAI lessons. The data from these variables are revealed using questionnaires and documentation.

In Online-based Distance Learning variables, the assessment was conducted using questionnaires with 4 indicators, among which are interactivity, independence, accessibility, enrichment, by asking 18 questions. Based on the respondents' responses, it is known that the average value of the whole is 88.7 , so online-based distance learning is in the excellent category.

\section{Student Learning Outcome Variables}

In the student learning outcome variable, obtained based on documentation recapitulation of the value of student learning results of grade $\mathrm{X}$ MIPA A at SMA Negeri 5 Bogor odd semester 2020/2021 in the form of results of odd midterm exam scores. Based on the calculations, it is known that the results of research on student learning outcomes can be obtained the lowest score of 64 and the highest score of 90 . The recapitulation of students' learning outcomes amounted to 831, with an average of 77.7. From the table of results of the frequency of student learning outcomes above, it is known that there are 6 students with vulnerable grades (64 - 66), 10 students with vulnerable grades (6769), 10 students with vulnerable grades (70-72), 10 students with vulnerable grades (73-75), 21 students with vulnerable grades (76-78), 10 students with vulnerable grades (79-81), 10 students with vulnerable grades (82-84), 9 students with vulnerable grades (85-87), and 21 students with vulnerable grades (88-99). So it can be concluded that the value of students' learning outcomes in PAI lessons at SMA Negeri 5 Bogor obtained good grades.

The criteria used in determining the validity of the statements used in this study are as follows: $(\alpha=5 \%$ ), degree of freedom $(\mathrm{df})=\mathrm{n}-2=107-2=105$, obtained $\mathrm{r}$ table $=0.1900$. The question item is said to be valid if $\mathrm{r}$ counts $>\mathrm{r}$ table. note that the overall calculated $r$-value of the indicator tested is positive and greater than the table $r$. Then it can be concluded, that the entire indicator item used in this study passed the validity test and declared valid. To measure reliability using statistical tests is Alpha Cronbach $(\alpha)$. A construct or variable is said to be reliable if it provides an Alpha coefficient value greater than 0.60 . Here is the reliability table of the results of the study:

Table 1

Reliability Statistics

\begin{tabular}{|c|c|}
\hline $\begin{array}{c}\text { Cronbach's } \\
\text { Alpha }\end{array}$ & $\begin{array}{c}\mathrm{N} \text { of } \\
\text { Items }\end{array}$ \\
\hline .882 & 18 \\
\hline
\end{tabular}


The reliability test results above showed that the Alpha coeffesient value of the variable studied showed a result of 0.882 which has a coefesien value of more than 0.6. Thus it is concluded that the measuring instruments used in this study are reriabel.

Normality testing is conducted to determine the normality of data distribution. Test normality data in this study using Klomograv-Smirnov test (KS). data processing conducted with IBM SPSS22 statistics analysis program, the normality test results are contained in Table 5. as follows:

Table 2

One-Sample Kolmogorov-Smirnov Test

\begin{tabular}{|ll|r|}
\hline & & Unstandardized Residual \\
\hline $\mathrm{N}$ & & 107 \\
Normal & Mean & .0000000 \\
Parameters & \\
& Std. & 7.03653750 \\
Most Extreme & Deviation & Absolute \\
Differences & Positive & .047 \\
& Negative & .045 \\
Test Statistic & & -.047 \\
Asymp. Sig. (2-tailed) & .047 \\
\hline
\end{tabular}

a. Test distribution is Normal.

Based on the normality test of variable $\mathrm{X}$ against variable $\mathrm{Y}$ with klomogrov-Smirnov the test obtained asymp (2-tailed) signification of 0.200 greater than 0.05, it can be concluded that the variable is normally distributed.

Testing this hypothesis using simple linear regression using ibm SPSS22 statistical program, the results of this research hypothesis test are found in Table 3. as follows:

Table 3

Variables Entered/Removed ${ }^{\mathrm{a}}$

\begin{tabular}{|l|l|l|l|}
\hline Model & $\begin{array}{l}\text { Variables } \\
\text { Entered }\end{array}$ & $\begin{array}{c}\text { Variables } \\
\text { Removed }\end{array}$ & Method \\
\hline 1 & $\begin{array}{l}\text { Pjj } \\
\text { Online }\end{array}$ & & Enter \\
\hline
\end{tabular}

a. Dependent Variable: Learning Outcomes

b. All requested variables entered.

This study used 2 variables, the first variable independent variables are online-based distance learning $(\mathrm{X})$, and the second dependent variable is student learning outcomes (Y), online-based distance learning obtained from questionnaires disseminated. While the students' learning results are obtained from documentation recapitulation of the value of student learning outcomes. 
Questionnaires have been tested for validity and reliability to determine how much the instrument collation is.

Table 4

Model Summary ${ }^{b}$

\begin{tabular}{|c|c|c|c|c|}
\hline Model & $\mathrm{R}$ & $\begin{array}{c}\mathrm{R} \\
\text { Square }\end{array}$ & $\begin{array}{l}\text { Adjusted } \\
\text { R Square }\end{array}$ & $\begin{array}{c}\text { Std. } \\
\text { Error of } \\
\text { the } \\
\text { Estimate }\end{array}$ \\
\hline 1 & $.364^{a}$ & .133 & .125 & 6.696 \\
\hline
\end{tabular}

a. Predictors: (Constant), Pjj Online

b. Dependent Variable: Learning Outcomes

Spss output summary model in Table 7, known coefficient determination value of $\mathrm{r}$ square of 0.133 , which is multiplied by 100 then the result is $13.3 \%$, it assumes that $13.3 \%$ of online-based distance learning affects the learning outcomes at SMA Negeri 5 Bogor, and still $86.7 \%$ other unknown influences.

Table 5

ANOVAa

\begin{tabular}{|c|c|c|c|c|c|}
\hline Model & $\begin{array}{l}\text { Sum of } \\
\text { Squares }\end{array}$ & Df & $\begin{array}{l}\text { Mean } \\
\text { Square }\end{array}$ & $\mathrm{F}$ & Sig. \\
\hline 1 Regression & 721.053 & 1 & 721.053 & 16.084 & $.000^{\mathrm{b}}$ \\
\hline Residual & 4707.134 & 105 & 44.830 & & \\
\hline Total & 5428.187 & 106 & & & \\
\hline
\end{tabular}

a. Dependent Variable: Learning Outcomes

b. Predictors: (Constant), Pjj Online

Spss ANOVA output results, known coefficient $f$ calculated value of 16,084 with a signification rate of 0.000 smaller than 0.05 , it can be concluded that these regression results can be used to predict student learning outcomes.

Table 6

Coefficients $^{a}$

\begin{tabular}{|c|c|c|c|c|c|}
\hline \multirow[b]{2}{*}{ Model } & \multicolumn{2}{|c|}{$\begin{array}{c}\text { Unstandardized } \\
\text { Coefficients }\end{array}$} & \multirow{2}{*}{$\begin{array}{c}\text { Standardized } \\
\text { Coefficients } \\
\text { Beta }\end{array}$} & \multirow[b]{2}{*}{$\mathrm{T}$} & \multirow[b]{2}{*}{ Sig. } \\
\hline & B & $\begin{array}{l}\text { Std. } \\
\text { Error }\end{array}$ & & & \\
\hline 1 (Constant) & 47.505 & 7.569 & & 6.276 & .000 \\
\hline Pji Online & .379 & .095 & .364 & 4.011 & .000 \\
\hline
\end{tabular}

a. Dependent Variable: Learning Outcomes 
SPSS output result in Table 4.11 Test result t test, known $t$ count of 4,011 , judging from $t$ count $4,011>t$ table 1,982 . So it can be concluded that Ho was rejected, which means $\mathrm{Ha}$ was accepted or there was a significant influence between online-based distance learning and student learning outcomes at SMA Negeri 5 Bogor. The signification value obtained by 0.000 $<$ the probability value of 0.05 . So it can be concluded ho rejected, which means there is a significant influence between online-based distance learning on student learning outcomes.

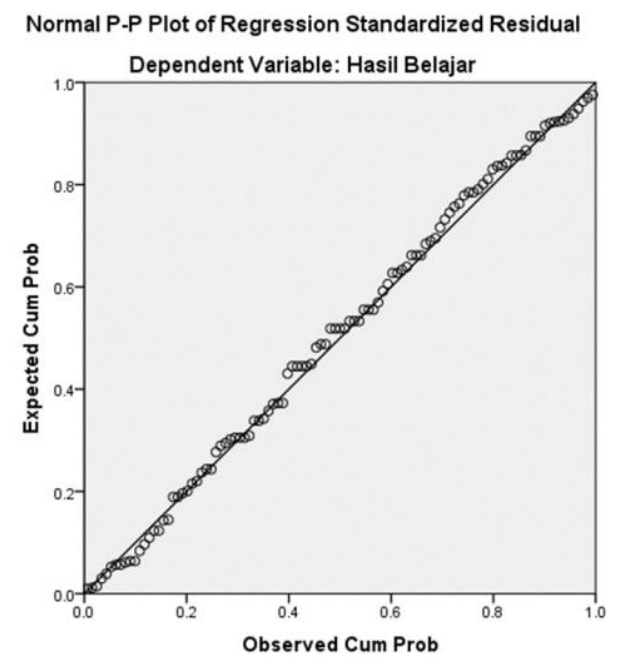

Gambar 1 Normal Probability Plot

From figure 1 of SPSS output above, it is known that the data distribution on a straight line is not spread far, thus it can be concluded that the normality requirements can be met the same as the previous normality test.

The results of the questionnaire on the application of online-based distance learning with an average score of 88.7 and the results of recapitulation of student learning outcomes in PAI lessons with an average of 77.7 can be concluded that the research is good or appropriate.

\section{E. Discussions}

Hypothetical test results using simple linear regression with the results of t count 4011 with signification 0.000 , judging from $t$ count 4,011 > t table 1.9828, then it can be concluded Ho rejected, which means $\mathrm{Ha}$ accepted or there is a significant influence between online-based distance learning on student learning outcomes at SMA Negeri 5 Bogor.

Online-based distance learning does not completely affect students' learning outcomes in PAI lessons, from $r$ square 0.133 which is divided to $13.3 \%$ means that there are still many other unknown influences. Although there is an influence between online-based distance learning and student learning outcomes 
in PAI lessons, there are still many factors that influence student learning outcomes during the Covid-19 pandemic that are not described in this study.

The findings in this study are in line with previous research conducted by Annida Fauziah the results showed that the average grade of students in the first semester with face-to-face learning was lower than the average score of students in the second semester with distance learning. The average grade of first-semester students is 66.07 while the average score of students in the second semester is 73.62. the study showed that distance learning affects students' learning outcomes. ${ }^{16}$ Findings of the study showed that the principle of blended learning synergize a balanced combination between face-to-face and online learning. It can apply blended learning to PAI learning and is quite successful. ${ }^{17}$

The next relevant research is research conducted by Niken Septantiningtyas entitled The Influence OfDistance Learning With Google Class App On Learning Outcomes. students' research is an application of research following the learning trend 4.0, namely the application of Online Applications as IT-Based Learning Media that has been developed by Google. The results of his research stated that Student learning motivation with google class model learning is better than student learning motivation with learning Conventional. ${ }^{18}$ The results showed that the implementation of e-learning was effective as a distance learning strategy during coronavirus disease (Covid-19) pandemic. ${ }^{19}$ Teacher-parent communication was optimized via online media, e.g. social media, digital mutaba'ah books (communication book: a teacher-parent daily communication book) based on Google form applications, or offline media, e.g. printed Mutaba'ah books. ${ }^{20}$

\section{F. Conclusion}

Based on the results of data analysis preceded by testing of research instruments, namely validity and reliability tests showed that all questions in the questionnaire were valid and reliable. Furthermore, a classic assumption test is performed stating that the regression model used is normally distributed. Then based on the results of hypothesis testing, it can be concluded as follows: Onlinebased Distance Learning positively affects and signification of students' learning

16 Annida Fauziah and Via Suvianti, "Pengaruh Pembelajaran Jarak Jauh Terhadap Hasil Belajar Fisika Di Masa COVID-19 Pada Siswa Kelas X IPA SMA Bina Machmud," Prosiding Seminar Nasional Pendidikan Fisika Untirta 3 (2020): 406.

17 Agus Setiawan, "Conceptual of Blended Learning as Islamic Education Study Program Learning Reform Action in Digital Era 4.0," SYAMIL: Jurnal Pendidikan Agama Islam (Journal of Islamic Education) 7, no. 2 (December 1, 2019): 119-29, https://doi.org/10.21093/sy.v7i2.1827.

${ }^{18}$ Niken Septantiningtyas, "PENGARUH PEMBELAJARAN JARAK JAUH DENGAN APLIKASI GOOGLE CLASS TERHADAP HASIL BELAJAR MAHASISWA,” Edureligia 2 (2018): 5.

${ }^{19}$ Dedi Prestiadi, "Effectiveness of E-Learning Implementation as a Distance Learning Strategy during Coronavirus Disease (Covid-19) Pandemic," PROCEEDING UMSURABAYA 0, no. 0 (September 8, 2020), http://journal.um-surabaya.ac.id/index.php/Pro/article/view/5950.

20 Sopiah Sopiah, "Reinforcing Character Education Values on Islamic Education in the Time of Distance Learning," Edukasia Islamika, December 31, 2020, 175-88, https://doi.org/10.28918/jei.v5i2.3189. 
outcomes in PAI lessons at SMA Negeri 5 Bogor. The test result of this hypothesis is seen from the test value $t$, that the calculated $t$ value in the OnlineBased Distance Learning variable is 4,011 with a significant rate of 0.000 . Because the $\mathrm{t}$ count value is greater than the $\mathrm{t}$ table which is 4,011 $>1,982$ and the signification value is $0.000<0.05$ then $\mathrm{Ho}$ is rejected and $\mathrm{Ha}$ is accepted. The $\mathrm{r}$ square score of 0.133 , it assumes that students' learning outcomes (Y) in PAI lessons are influenced by online-based distance learning $(\mathrm{X})$ by $13.3 \%$ while the remaining $86.7 \%$ is influenced by other factors outside this study 


\section{BIBLIOGRAPHY}

Amalia Hapsari, Swita, and Heri Pamungkas. "Pemanfaatn Google Classroom Sebagai Media Pembelajaran Online Di Universitas Dian Nuswantoro." WACANA 18 (2019): 229.

Daulay, Haidar Putra. Pemberdayaan Pendidikan Agama ISlam Di Sekolah. jakarta: Kencana, 2016.

Fauziah, Annida, and Via Suvianti. "Pengaruh Pembelajaran Jarak Jauh Terhadap Hasil Belajar Fisika Di Masa COVID-19 Pada Siswa Kelas X IPA SMA Bina Machmud." Prosiding Seminar Nasional Pendidikan Fisika Untirta 3 (2020): 406.

Haqien, Danin, and Aqiilah Rahman. "Pemanfaatan Zoom Meeting Untuk Proses Pembelajaran Pada Masa Covid-19." Sususnan Artikel Pendidikan 5 (2020): 52.

Muhyani. Metodologi Penelitian, Cara Mudah Melakukan Penelitian. Bogor Jawa Barat: UIKA PRESS, 2019.

Prestiadi, Dedi. "Effectiveness of E-Learning Implementation as a Distance Learning Strategy during Coronavirus Disease (Covid-19) Pandemic." PROCEEDING UMSURABAYA 0, no. 0 (September 8, 2020). http://journal.umsurabaya.ac.id/index.php/Pro/article/view/5950.

Purwanto. Evaluasi Hasil Belajar. Yogyakarta: Pustaka Pelajar, 2009.

Ritonga, Apri Wardana, Sri Zulfida, Mahyudin Ritonga, Eva Ardinal, and Dini Susanti. "The Use of E-Learning as an Online Based Arabic Learning Media for Students." Journal of Physics: Conference Series 1933, no. 1 (June 2021): 012127. https://doi.org/10.1088/1742-6596/1933/1/012127.

Riyanto, Selamet. Metode Riset Penelitian Kuantitatif. Yogyakarta: Deepublish, 2020.

Rusman. Pembelajaran Berbasis Teknologi Informasi Dan Komunikasi. Jakarta: PT Rajagrafindo Persada, 2011.

Septantiningtyas, Niken. "PENGARUH PEMBELAJARAN JARAK JAUH DENGAN APLIKASI GOOGLE CLASS TERHADAP HASIL BELAJAR MAHASISWA.” Edureligia 2 (2018): 5.

Setiawan, Agus. "Conceptual of Blended Learning as Islamic Education Study Program Learning Reform Action in Digital Era 4.0." SYAMIL: Jurnal Pendidikan Agama Islam (Journal of Islamic Education) 7, no. 2 (December 1, 2019): 119-129. https://doi.org/10.21093/sy.v7i2.1827.

"Implementation of Islamic Education Study Program Learning Based on Blended Learning in the Industrial Era 4.0 at IAIN Samarinda." Dinamika Ilmu 19, no. 2 (December 15, 2019): 305-321. https://doi.org/10.21093/di.v19i2.1781. 
"Merancang Media Pembelajaran PAI di Sekolah (Analisis Implementasi Media Pembelajaran Berbasis PAI)." Darul Ulum: Jurnal Ilmiah Keagamaan, Pendidikan dan Kemasyarakatan, December 1, 2019, 223-240.

Sopiah, Sopiah. "Reinforcing Character Education Values on Islamic Education in the Time of Distance Learning." Edukasia Islamika, December 31, 2020, 175188. https://doi.org/10.28918/jei.v5i2.3189.

Sugiyono. Metode Penelitian Kuantitatif, Kualitatif, R\&D. BAndung: Alfabeta, 2013.

Sukmadinata. Model Penelitian Pendidikan. PT Remaja Rosdakarya, 2011.

Supyatningsih, Nyoman. E-Learning Untuk Pembelajaran Abad 21 Dalam Menghadapi Era Revolusi Industri 4.0, 2020.

Susanto. Belajar Dan Pembelajaran Di Sekolah Dasar. Jakarta: Kencana, 2013.

Yungga, Kharisma Danag. "Pengembangan Media Dan Strategi Pembelajaran Untuk Mengatasi Permasalahan Pembelajaran Jarak Jauh Di Pandemi Covid-19." Guru Kita 4, no. 3 (2020): 52. 